\begin{tabular}{|l|l|l||}
\hline \multicolumn{2}{|c|}{ PublisherInfo } \\
\hline \hline PublisherName & $:$ & BioMed Central \\
\hline \hline PublisherLocation & $:$ & London \\
\hline \hline PublisherImprintName & $:$ & BioMed Central \\
\hline \hline
\end{tabular}

\title{
Two breaks make a translocation
}

\begin{tabular}{|l|l|l||}
\hline \multicolumn{2}{|c|}{ ArticleInfo } \\
\hline \hline ArticleID & $:$ & 3703 \\
\hline \hline ArticleDOI & $:$ & $10.1186 /$ gb-spotlight-20000616-02 \\
\hline \hline ArticleCitationID & $:$ & spotlight-20000616-02 \\
\hline \hline ArticleSequenceNumber & $:$ & 140 \\
\hline \hline ArticleCategory & $:$ & Research news \\
\hline \hline ArticleFirstPage & $:$ & 1 \\
\hline \hline ArticleLastPage & $:$ & 2 \\
\hline \hline & & RegistrationDate : 2000-06-16 \\
ArticleHistory & $:$ & OnlineDate \\
\hline \hline ArticleCopyright & $:$ & BioMed Central Ltd2000-06-16 \\
\hline \hline ArticleGrants & $:$ & \\
\hline \hline ArticleContext & $:$ & 130591111 \\
\hline \hline
\end{tabular}




\section{William Wells}

Email: wells@biotext.com

There are multiple ways in which double-stranded breaks (DSBs) in DNA can be repaired or recombine with other DNA molecules. Under some of these conditions it is theoretically possible that a single DSB could invade a region of homology and cause a translocation. But in the 8 June Nature Richardson and Jasin find that mouse cells with a single DSB often repair the break with homologous sequences from another location, but only cells with two DSBs experience translocation events (Nature 2000, 205:697-700). Richardson and Jasin introduce DSBs by adding a rare-cutting restriction enzyme gene and allowing the enzyme to act on a site within an introduced drug-resistance gene. This system should help in studies of how to suppress translocation events.

\section{References}

1. Homology-directed repair is a major double-strand break repair pathway in mammalian cells.

2. Nature Magazine, [http://www.nature.com/nature/]

3. Introduction of double-strand breaks into the genome of mouse cells by expression of a rare-cutting endonuclease. 